\title{
Determination of Haematological Effects of Extracts of Reseda sphenocleoides Leaves in Albino Rats Infected with Entamoeba histolytica
}

\author{
Mansour Abdulnabi Hadi Mehdi ${ }^{1, *}$, Vidya Pradhan ${ }^{1}$, Mazahar Farooqui ${ }^{2}$, Fadel Yousif Salah Alarabi ${ }^{1}$, \\ Gozif Mohammed Nasr Omar ${ }^{3}$
}

${ }^{1}$ Department of Zoology, Dr. Rafiq Zakaria College for Women, Aurangabad, Maharashtra, INDIA.

2Department of Chemistry, Maulana Azad College of Art, Science and Commerce, Aurangabad, Maharashtra, INDIA.

${ }^{3}$ Department of Biochemistry, Dr. Babasaheb Ambedkar Marathwada University, Aurangabad, Maharashtra, INDIA.

\begin{abstract}
Objectives: This research was designed to examine improvements in some heamatological parameters of Entamoeba histolytica-infected rats treated with extracts of Reseda sphenocleoides leaves. Methods: Twenty rats weighing between 200-220 g were divided into 4 groups (Each per group containing 5 rats). Fifteen rats were infected by oral administration $\left(17 \times 10^{3} \mathrm{cell} / \mathrm{ml}\right)$ of E. histolytica obtained from the stool. Infected rats were classified in differentiated three groups $A, B, C$. In addition, the negative control group $\mathrm{E}$. The groups ( $\mathrm{A}$ and $\mathrm{B}$ ) were administered with the ethanolic and aqueous extracts at the dose of $500 \mathrm{mg} / \mathrm{kg}$ body weight/day, the group C was administered with metronidazole, in a dose $500 \mathrm{mg} / \mathrm{kg}$ body weight (Positive control group). The negative control group E was uninfected and untreated. The hematological parameters in the different groups were monitored throughout the period of study which was 10 days on three stages. Results: The results show a significant increase at $P \leq 0.05$ in Red Blood Cell Count (RBC), Haemoglobin (Hb), Hematocrit (HCT), Mean Cell Volume (MCV), Red Cell Distribution Width (RDW), Procalcitonin Test (PCT) and Lymphocyte (LY) in groups which treated with $R$. sphenocleoides extracts compare with metronidazole drug and the negative control group during treatment stages. While the results show a decrease of significant at $P \leq 0.05$ in Platelet (PLT), Mean Platelet Volume (MPV), Platelet Distribution Width (PDW), Total White Blood Cell (WBC), Monocyte (MO) and Granulocytes (GR) in groups which treated with $R$. sphenocleoides extracts in comparison with the control groups of rats. The results also indicate no changes of significance at $P>0.05$ in Mean Corpuscular Hemoglobin $(\mathrm{MCH})$ and Mean Corpuscular Hemoglobin Concentration $(\mathrm{MCHC})$ during treatment stages. Conclusion: The findings of this study, the efficiency of $R$. sphenocleoides extracts in improving blood standards in rats infected with E. histolytica.
\end{abstract}

Key words: Reseda sphenocleoides, Extract, Entamoeba histolytica, Haematological, Albino rats.

\section{INTRODUCTION}

Amoebiasis infection represents a large and serious medical and public health problem in developing countries due to its nutritional consequences. ${ }^{1}$ It is a dangerous disease that is transmitted to humans by infection with this parasite occurred by water and food contaminated with cysts of Entamoeba bistolytica. ${ }^{2}$ The trophozoites active invades of the intestines muscular and penetrates the intestinal muscle wall and feeds on the erythrocyte. ${ }^{3}$ The trophozoites continue to corrode the intestinal epithelium, leading to ulcers in the intestinal muscular. ${ }^{4}$ Most of the infection is asymptomatic; however, in symptomatic patients, it is associated with malabsorptive diarrhea. ${ }^{5}$ Also, the incidence infection of these parasites can lead to low birth weight, reduced productivity in adulthood, stunted growth, reduced
Submission Date: 17-04-2020; Revision Date: 17-07-2020; Accepted Date: 15-01-2021

DOI: 10.5530/ijper.55.2.81 Correspondence: Mr. Mansour Abdulnabi Hadi Mehdi Department of Zoology, Dr. Rafiq Zakaria, College for Women, Navkhanda, Aurangabad, Maharashtra, INDIA.

Phone no: +91 7709623233 Email id: mansourabdulnabi@gmail.com

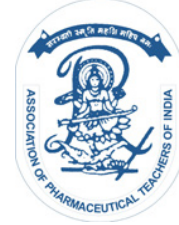

www.ijper.org 
hemoglobin concentration and iron level in the blood which leads to anemia. ${ }^{6}$

World health organization reported that infect $10 \%$ of the world's population, up to 50 million cases of invasive amoebiasis and it is responsible for 100,000 deaths per year worldwide it ranks third among parasitic diseases that result to death worldwide; if not in second to malaria as a protozoan cause of death. ${ }^{7}$ The disease is prevalent worldwide, but the highest prevalence rates have been recorded in developing countries, Indian sub-regions, parts of Central and Southern America and tropical regions of Africa. ${ }^{8}$

Despite decades of research, metronidazole remains a drug of therapy in option first for the treatment of amoebiasis, ${ }^{9}$ though that is the resistance of drug by $E$. bistolytica, so resulted in the urgent want in increasing doses to get over the infection. In addition, this drug has several untoward side effects such as headaches, metallic taste in the mouth and vomiting as well as neurotoxicity. 'The resistance of amoebiasis to drugs such as metronidazole has become a serious problem in developing countries. ${ }^{10}$

Reseda sphenocleoides Deflers belongs to the family Resedaceae is endemic to southwest Arabia, Hadramaut, Aden-Yemen. ${ }^{11}$

The leaves of $R$. sphenocleoides were used as a tranquilizer and it is useful in the treatment of insomnia. ${ }^{11}$

R. sphenocleoides leaves were used in traditional medicine in the Yemeni countryside to treat many cases of diarrhea, especially those that occur in their animals. ${ }^{12}$ The $R$. sphenocleoides leaves showed anti-helminths, a tranquilizer and diuretic. ${ }^{13}$

The study aimed to investigate the effect of $R$. sphenocleoides leaves extracts on haematological changes in rats infected by E. histolytica.

\section{MATERIALS AND METHODS \\ Plant collection}

The R. sphenocleoides leaves were collected from the Rdfan villages in Lahj governorate, Yemen $\left(13^{\circ} 26^{\prime} \mathrm{N}\right.$, $\left.44^{\circ} 59^{\prime} \mathrm{W}\right)$. The selected leaves were identified and authenticated by Dr. Othman Saad Saeed Al-Hawshabi in the Department of Biology, Faculty of Science at Aden University, Aden, Yemen. Specimen number KA144/19/20/34. leaves of $R$. sphenocleoides were washed by using tap water to take off filth and dust on the roof after that the leaves were dried under a shade and grinded into powder by using an electrical mixer.

\section{Preparing of plant extracts}

The powdered that is dray of R. sphenocleoides leaves, $40 \mathrm{~g}$ was weighed and dissolved in $400 \mathrm{ml}$ of ethanol were extracted in a Soxhlet apparatus at $50-55^{\circ} \mathrm{C}$, till the color extract disappeared to get an extract, also, $40 \mathrm{~g}$ was weighed and dissolved in $400 \mathrm{ml}$ of distilled water in a beaker by mixing using a magnetic stirrer for $24 \mathrm{hr}$. The mixture was filtrated from each extract by four layers of gauze cloth. The filtrate was centrifuged at $3000 \mathrm{rpm}$ for $10 \mathrm{~min}$. The supernatant was collected and filtered through Whatman No. 1 filter paper. The solvent was evaporated lay Rotary evaporator. After that, it was transferred to an incubator for 24 hrs at $50^{\circ} \mathrm{C} ., 14$

\section{Qualitative phytochemical testing}

The crude extracts were subjected to qualitative phytochemical screening to determine the absence or presence of chosen chemical constituents by using analysis methods which are described by Mehdi et al. ${ }^{6}$

\section{Experimental animals and design}

3-3.5 months old healthy white albino rats (Rattus norvegicus) weighing between $200 \mathrm{~g}$ and $220 \mathrm{~g}$ were used in this study. The rats were acclimatized to laboratory conditions for two weeks and were fed ad libitum food and water. Ethical guidelines and procedures for handling experimental animals were followed. Twenty white albino rats were used in this study; fifteen rats were infected by oral administration $\left(17 \times 10^{3} \mathrm{cell} / \mathrm{ml}\right)$ of E. histolytica obtained from the stool. Infected rats were divided into three groups in additional to, control group. Each group containing five rats, which were orally administered for 10 days.

Group A: Infected and administered with ethanolic extract (500 $\mathrm{mg} / \mathrm{kg}$ body weight).

Group B: Infected and administered with aqueous extract (500 $\mathrm{mg} / \mathrm{kg}$ body weight).

Group C: Infected and administered with metronidazole (500 mg/kg body weight).

Group E: The control group uninfected and untreated.

\section{Collecting samples of blood}

The samples of blood were collected before the beginning of treatment (Pre-treatment stage), then on the $5^{\text {th }}$ day of treatment (Mid-treatment stage) and finally on the $10^{\text {th }}$ day of treatment (Post-treatment stage) in each group from the vein at region next to the eye using capillary tubes. Then the blood was put in sterile vials (1.0-2.0 ml) containing EDTA which were used as an anticoagulant for the blood. After that blood was tested for complete blood count (CBC).

\section{Determination of haematological parameters}

The haematological parameters were determined using the method as described by Mehdi et al. ${ }^{9}$ 


\section{Statistical analysis}

The results of the present study were analyzed by Genstat ${ }^{\circledR}$ (Version 5.2) using general treatment structure (no blocking), factorial experiment, with 5 replications. Least significant different test (LSD) was used to test the difference between means (groups) at $P \leq 0.05$ and was considered significant.

\section{RESULTS}

\section{Qualitative tests of some active compounds in plant extracts}

Preliminary phytochemical screening of the constituents of the extracts is useful as an exercise in identifying the possible phytochemical groups present in each extract in the plants. Phytochemical screening of R. sphenocleoides extracts showed the existence of tannins, flavonoids, glycosides, phenols, resins, saponins, furanocoumarin, triterpenoids, amino acids and carbohydrates in ethanolic and aqueous extracts of $R$. sphenocleoides leaves. The ethanolic extract contains alkaloids while aqueous extract does not alkaloids, but terpenes and sterols were absent in both extracts Table 1 .

\section{Effects of extracts of $\boldsymbol{R}$. sphenocleoides leaves on erythrocytic parameter profiles in albino rats infected with E. histolytica.}

Extracts of the leaf from R. sphenocleoides caused changes in erythrocytes and connected parameter profiles in $E$. histolytica-infected rats (Table 2). Before the administration of extracts, the results showed that the heamatological profile of rats which were infected by E. histolytica a significant decrease $(P \leq 0.05)$ in RBC, Hb, HCT, MCV and RDW in pre-treatment stage in comparison with the negative control group (Table 2). Also, in the same stage, the rats infected with E. histolytica showed a significant increase $(P \leq 0.05)$ in MCHC compared with negative control (Pre-treatment stage). However, no significant change $(\mathrm{P}>0.05)$ in the $\mathrm{MCH}$ level was observed in the same stage.

In five days after (Mid-treatment stage) of administration with extracts of $\mathrm{R}$. sphenocleoides at the dose levels of $500 \mathrm{mg} / \mathrm{kg}$ and $500 \mathrm{mg} / \mathrm{kg}$ of metronidazole, a significant increase was observed $(P \leq 0.05)$ in $\mathrm{RBC}, \mathrm{Hb}, \mathrm{HCT}$ and RDW in groups which were treated by ethanolic and aqueous extracts of R. sphenocleoides in comparison with pre-treatment stage and with negative control and

\begin{tabular}{|c|c|c|c|}
\hline Group & Test & Observation & Inference \\
\hline Alkaloids & Mayer's reagent & $\begin{array}{l}\text { E - white precipitate } \\
\text { A - no precipitate }\end{array}$ & $\begin{array}{l}+ \\
-\end{array}$ \\
\hline Flavonoids & Ethyl alcohol + Potassium hydroxide & $\begin{array}{l}E-\text { yellow colour } \\
A-\text { yellow colour }\end{array}$ & $\begin{array}{l}+ \\
+\end{array}$ \\
\hline Glycosides & Benedict's reagent & $\begin{array}{l}\mathrm{E} \text { - red precipitate } \\
\mathrm{A} \text { - red precipitate }\end{array}$ & $\begin{array}{l}+ \\
+\end{array}$ \\
\hline Phenols & Ferric chloride & $\begin{array}{l}E \text { - green colour } \\
A-\text { green colour }\end{array}$ & $\begin{array}{l}+ \\
+\end{array}$ \\
\hline Resins & Ethyl alcohol + Hydrochloric acid & $\begin{array}{l}\text { E - turbidity } \\
\text { A - turbidity }\end{array}$ & $\begin{array}{l}+ \\
+\end{array}$ \\
\hline Saponins & Foam test and Mercuric chloride & $\begin{array}{l}\text { E - white precipitate and frothing } \\
\text { A-white precipitate and frothing }\end{array}$ & + \\
\hline Terpenes and Sterols & $\begin{array}{c}\text { Chloroform + Acetic acid + Sulfuric } \\
\text { acid }\end{array}$ & $\begin{array}{l}E-\text { no colour } \\
A-\text { no colour }\end{array}$ & - \\
\hline Tannins & Lead acetate & $\begin{array}{l}\text { E - gelatinous precipitate } \\
\text { A - gelatinous precipitate }\end{array}$ & $\begin{array}{l}+ \\
+\end{array}$ \\
\hline Furanocoumarin & Potassium hydroxide & $\begin{array}{l}E \text { - red color or purple } \\
A \text { - red color or purple }\end{array}$ & $\begin{array}{l}+ \\
+\end{array}$ \\
\hline Triterpenoids & Chloroform + Sulfuric acid & $\begin{array}{l}E \text { - red color or purple } \\
A \text { - red color or purple }\end{array}$ & $\begin{array}{l}+ \\
+\end{array}$ \\
\hline Amino acids & Ninhydrin Reagent & $\begin{array}{l}E \text { - purple colour } \\
A \text { - purple colour }\end{array}$ & $\begin{array}{l}+ \\
+\end{array}$ \\
\hline Carbohydrates & Mayer's reagent & $\begin{array}{l}E \text { - violet color ring } \\
A \text { - violet color ring }\end{array}$ & + \\
\hline
\end{tabular}

Key: $\mathrm{A}$ = Aqueous extract, $\mathrm{E}$ = Ethanolic extract, + = present, - = absent. 


\begin{tabular}{|c|c|c|c|c|c|c|}
\hline Parameters & $\begin{array}{c}\text { Type } \\
\text { Treatment }\end{array}$ & Pre-Treatment & Mid-Treatment & Post-Treatment & Means & LSD $5 \%$ \\
\hline \multirow{4}{*}{$\begin{array}{c}\text { RBC } \\
\left(10^{6} / \mathrm{mm}^{3}\right)\end{array}$} & Control & 8.690 & 8.377 & 8.887 & 8.651 & \multirow{5}{*}{0.2930} \\
\hline & Metronidazole & 6.987 & 8.040 & 8.070 & 7.699 & \\
\hline & Ethanolic extract & 6.547 & 7.003 & 7.713 & 7.087 & \\
\hline & Aqueous extract & 6.090 & 6.427 & 7.440 & 6.652 & \\
\hline \multicolumn{2}{|l|}{ Means } & 7.08 & 7.46 & 8.03 & 7.52 & \\
\hline \multirow{4}{*}{$\begin{array}{c}\mathrm{Hb} \\
(\mathrm{g} / \mathrm{dL})\end{array}$} & Control & 13.97 & 14.77 & 15.97 & 14.90 & \multirow{5}{*}{0.871} \\
\hline & Metronidazole & 12.17 & 15.23 & 15.60 & 14.33 & \\
\hline & Ethanolic extract & 12.23 & 14.27 & 15.73 & 14.08 & \\
\hline & Aqueous extract & 11.37 & 15.30 & 16.00 & 14.22 & \\
\hline \multicolumn{2}{|l|}{ Means } & 12.44 & 14.89 & 15.83 & 14.38 & \\
\hline \multirow{4}{*}{$\begin{array}{l}\text { HCT } \\
(\%)\end{array}$} & Control & 41.20 & 45.40 & 47.67 & 44.76 & \multirow{5}{*}{0.894} \\
\hline & Metronidazole & 35.40 & 43.37 & 46.97 & 41.91 & \\
\hline & Ethanolic extract & 41.73 & 42.37 & 47.20 & 43.77 & \\
\hline & Aqueous extract & 40.33 & 42.10 & 47.00 & 43.14 & \\
\hline \multicolumn{2}{|l|}{ Means } & 39.67 & 43.31 & 47.21 & 43.40 & \\
\hline \multirow{4}{*}{$\begin{array}{l}\text { MCV } \\
(\mathrm{mm} 3)\end{array}$} & Control & 56.17 & 56.50 & 54.50 & 55.72 & \multirow{5}{*}{2.226} \\
\hline & Metronidazole & 50.90 & 53.80 & 58.77 & 54.49 & \\
\hline & Ethanolic extract & 52.70 & 53.97 & 56.47 & 54.38 & \\
\hline & Aqueous extract & 52.53 & 53.73 & 55.20 & 53.82 & \\
\hline \multicolumn{2}{|l|}{ Means } & 53.08 & 54.50 & 56.24 & 54.60 & \\
\hline \multirow{4}{*}{$\begin{array}{c}\text { MCH } \\
\text { (pg/cell) }\end{array}$} & Control & 18.70 & 18.37 & 19.30 & 18.79 & \multirow{5}{*}{1.062} \\
\hline & Metronidazole & 17.97 & 17.97 & 17.97 & 17.97 & \\
\hline & Ethanolic extract & 17.83 & 18.23 & 19.53 & 18.53 & \\
\hline & Aqueous extract & 19.57 & 19.73 & 20.07 & 19.79 & \\
\hline \multicolumn{2}{|l|}{ Means } & 18.52 & 18.58 & 19.22 & 18.77 & \\
\hline \multirow{4}{*}{$\begin{array}{r}\text { MCHC } \\
\text { (g/dL) }\end{array}$} & Control & 31.50 & 35.50 & 32.20 & 33.07 & \multirow{5}{*}{1.725} \\
\hline & Metronidazole & 35.90 & 35.87 & 35.40 & 35.72 & \\
\hline & Ethanolic extract & 34.80 & 34.23 & 33.07 & 34.03 & \\
\hline & Aqueous extract & 34.03 & 37.17 & 37.63 & 36.28 & \\
\hline \multicolumn{2}{|l|}{ Means } & 34.06 & 35.69 & 34.58 & 34.78 & \\
\hline \multirow{4}{*}{$\begin{array}{l}\text { RDW } \\
(\%)\end{array}$} & Control & 17.80 & 17.37 & 17.00 & 17.39 & \multirow{5}{*}{0.637} \\
\hline & Metronidazole & 15.87 & 16.00 & 17.30 & 16.39 & \\
\hline & Ethanolic extract & 16.10 & 17.40 & 17.43 & 16.98 & \\
\hline & Aqueous extract & 17.93 & 17.17 & 17.07 & 17.39 & \\
\hline \multicolumn{2}{|l|}{ Means } & 16.93 & 16.99 & 17.20 & 17.04 & \\
\hline
\end{tabular}

Least Significant Differences (LSD), Red Blood Cell (RBC), Hemoglobin (Hb), Haematocrit (HCT), Mean Cell Volume (MCV), Mean Corpuscular Hemoglobin (MCH), Mean Corpuscular Hemoglobin Concentration (MCHC), Red Cell Distribution Width (RDW).

metronidazole group. While the values of $\mathrm{MCV}, \mathrm{MCH}$ and MCHC showed a slight increase after five days of treatment but non-significant $(P>0.05)$ in comparison with the pre-treatment stage.

Table (2) shows the dose level of $500 \mathrm{mg} / \mathrm{kg}$ of extracts caused important increase $(P \leq 0.05)$ in $\mathrm{RBC}, \mathrm{Hb}$, HCT, MCV and RDW in all groups in ten days after administration of the ethanolic and aqueous extracts of $R$ sphenocleoides when compared with metronidazole group. Also, the results showed that $\mathrm{MCH}$ and $\mathrm{MCHC}$ have no significant differences $(P>0.05)$ when compared with the metronidazole group during the treatment period.

\section{Effects of extracts of $\boldsymbol{R}$. sphenocleoides leaves on platelets and their connected parameter profiles in albino rats infected with $E$. histolytica}

The leaf extracts of R. sphenocleoides caused changes in platelets and their connected parameters in normal profiles (Table 3). Before the administration (Pre-treatment stage) 


\begin{tabular}{|c|c|c|c|c|c|c|}
\hline Parameters & $\begin{array}{c}\text { Type } \\
\text { Treatment }\end{array}$ & Pre-Treatment & Mid-Treatment & Post-Treatment & Means & $\begin{array}{l}\text { LSD } \\
5 \%\end{array}$ \\
\hline \multirow{4}{*}{$\begin{array}{c}\text { PLT } \\
\left(10^{3} / \mu L\right)\end{array}$} & Control & 447 & 472 & 610 & 509.67 & \multirow{5}{*}{66.6} \\
\hline & Metronidazole & 916 & 673 & 505 & 698.00 & \\
\hline & Ethanolic extract & 689 & 611 & 535 & 611.67 & \\
\hline & Aqueous extract & 701 & 673 & 567 & 647.00 & \\
\hline \multicolumn{2}{|l|}{ Means } & 688.25 & 607.25 & 554.25 & 616.58 & \\
\hline \multirow{4}{*}{$\begin{array}{l}\text { PCT } \\
(\%)\end{array}$} & Control & 0.295 & 0.283 & 0.387 & 0.322 & \multirow{5}{*}{0.01303} \\
\hline & Metronidazole & 0.367 & 0.677 & 0.318 & 0.454 & \\
\hline & Ethanolic extract & 0.342 & 0.323 & 0.361 & 0.357 & \\
\hline & Aqueous extract & 0.347 & 0.357 & 0.368 & 0.342 & \\
\hline \multicolumn{2}{|l|}{ Means } & 0.338 & 0.410 & 0.359 & 0.367 & \\
\hline \multirow{4}{*}{$\begin{array}{c}\text { MPV } \\
\text { (fL) }\end{array}$} & Control & 6.600 & 6.000 & 6.367 & 6.322 & \multirow{5}{*}{0.1748} \\
\hline & Metronidazole & 6.600 & 6.167 & 6.000 & 6.256 & \\
\hline & Ethanolic extract & 6.400 & 6.400 & 6.300 & 6.367 & \\
\hline & Aqueous extract & 6.367 & 6.867 & 5.867 & 6.367 & \\
\hline \multicolumn{2}{|l|}{ Means } & 6.492 & 6.359 & 6.134 & 6.328 & \\
\hline \multirow{4}{*}{$\begin{array}{l}\text { PDW } \\
(\%)\end{array}$} & Control & 15.70 & 14.67 & 13.70 & 14.69 & \multirow{5}{*}{0.647} \\
\hline & Metronidazole & 18.97 & 16.47 & 17.30 & 17.58 & \\
\hline & Ethanolic extract & 15.83 & 17.03 & 12.92 & 15.28 & \\
\hline & Aqueous extract & 15.83 & 17.67 & 11.73 & 15.08 & \\
\hline \multicolumn{2}{|l|}{ Means } & 16.58 & 16.46 & 13.91 & 15.65 & \\
\hline
\end{tabular}

Least Significant Differences (LSD), Platelet (PLT), Procalcitonin Test (PCT), Mean Platelet Volume (MPV), Platelet Distribution Width (PDW)

of extracts, the results showed increased significantly $(P \leq 0.05)$ in PLT, PCT and PDW in E. bistolytica-infected rats in comparison with the negative control group (Table 3). In the same stage, the results showed that MPV has no significant different $(P>0.05)$ that is compared with the negative control group.

In five days after administration (Mid-treatment stage) of the ethanolic and aqueous leaves extracts of R. sphenocleoides, the dose level of $500 \mathrm{mg} / \mathrm{kg}$ caused changes in platelets and their connected parameters in rats infected with E. histolytica parasite (Table 3). The dose of $500 \mathrm{mg} / \mathrm{kg}$ caused a significant decrease in PLT and MPV in groups which were treated with extracts when compared with and pre-treatment stage. On one side, the results showed a significant increase in PCT and PDW in groups which were treated with extracts when compared with and pretreatment stage.

After ten days (Post-treatment stage) of administration, the dose level of $500 \mathrm{mg} / \mathrm{kg}$ caused a significant increase $(p<0.05)$ in PCT in comparison with the pre-treatment and the mid-treatment. However, the same dose caused a significant decrease in PLT, MPV and PDW when it is compared with the negative control group and the metronidazole group.

\section{Effects of extracts of $R$. sphenocleoides leaves on total WBC and differential WBC counts in albino rats infected with $E$. histolytica}

The WBC and the differential leucocytic counts values are presented in (Table 4). Before the administration of extracts, the results showed a significant increase $(P \leq 0.05)$ in WBC, MO and GR in E. histolytica-infected rats in comparison with the negative control. On the other hand, the results showed a significant decrease in LY in comparison with the negative control.

After five days (Mid-treatment stage) of administration with the extracts of $R$. sphenocleoides, a significant decrease was observed in WBC, MO and GR in all groups treated with extracts when it is compared with the pre-treatment stage and metronidazole group. The LY showed no significant increase $(P>0.05)$ when it is compared with the pre-treatment stage and comparison with the metronidazole group.

After ten days (Post-treatment stage) administration with extracts of $R$. sphenocleoides at the dose levels of $500 \mathrm{mg} / \mathrm{kg}$, there was a significant decrease observed $(P \leq 0.05)$ in $\mathrm{WBC}, \mathrm{MO}$ and GR in all groups treated in comparison with metronidazole group. But, there was a significant increase $(P<0.05)$ in the percentage of LY 
Table 4: Effects of ethanolic and aqueous leaves extracts of $R$. sphenocleoides on total WBC and differential WBC counts in albino rats infected with $E$. histolytica.

\begin{tabular}{|c|c|c|c|c|c|c|}
\hline Parameters & Type-Treatment & Pre-Treatment & Mid-Treatment & Post-Treatment & Means & LSD $5 \%$ \\
\hline \multirow{4}{*}{$\begin{array}{l}\text { WBC } \\
\left(10^{3}\right)\end{array}$} & Control & 8.07 & 7.27 & 9.20 & 8.18 & \multirow{5}{*}{1.402} \\
\hline & Metronidazole & 10.57 & 10.67 & 11.90 & 11.05 & \\
\hline & Ethanolic extract & 16.00 & 12.43 & 7.43 & 11.96 & \\
\hline & Aqueous extract & 15.37 & 12.03 & 8.03 & 11.81 & \\
\hline \multicolumn{2}{|l|}{ Means } & 12.50 & 10.60 & 9.14 & 10.75 & \\
\hline \multirow{4}{*}{$\begin{array}{l}\text { LY } \\
\text { (\%) }\end{array}$} & Control & 93.07 & 97.00 & 95.77 & 95.28 & \multirow{5}{*}{2.453} \\
\hline & Metronidazole & 88.97 & 89.93 & 92.00 & 90.30 & \\
\hline & Ethanolic extract & 87.37 & 91.20 & 92.87 & 90.48 & \\
\hline & Aqueous extract & 85.73 & 87.90 & 92.73 & 88.79 & \\
\hline \multicolumn{2}{|l|}{ Means } & 88.79 & 91.51 & 93.34 & 91.21 & \\
\hline \multirow{4}{*}{$\begin{array}{l}\text { MO } \\
(\%)\end{array}$} & Control & 3.97 & 2.00 & 3.30 & 3.09 & \multirow{5}{*}{1.956} \\
\hline & Metronidazole & 8.40 & 7.97 & 5.80 & 7.39 & \\
\hline & Ethanolic extract & 9.20 & 7.07 & 5.23 & 7.17 & \\
\hline & Aqueous extract & 10.20 & 9.90 & 5.47 & 8.52 & \\
\hline \multicolumn{2}{|l|}{ Means } & 7.94 & 6.74 & 4.95 & 6.54 & \\
\hline \multirow{4}{*}{$\begin{array}{l}\text { GR } \\
(\%)\end{array}$} & Control & 1.80 & 1.00 & 1.10 & 1.30 & \multirow{5}{*}{0.648} \\
\hline & Metronidazole & 2.63 & 2.10 & 2.20 & 2.31 & \\
\hline & Ethanolicn extract & 3.43 & 1.73 & 1.90 & 2.36 & \\
\hline & Aqueous extract & 4.07 & 2.20 & 2.10 & 2.79 & \\
\hline \multicolumn{2}{|l|}{ Means } & 2.98 & 1.76 & 1.83 & 2.19 & \\
\hline
\end{tabular}

Least Significant Differences (LSD), Total White Blood Cell (WBC), Lymphocyte (LY), Monocyte (MO), Granulocytes (GR).

counts at the dose level of $500 \mathrm{mg} / \mathrm{kg}$ after ten days of administration of the extracts in comparison with the metronidazole group.

\section{DISCUSSION}

\section{Phytochemical screening of extracts of R. sphenocleoides leaves}

Results of qualitative tests were shown for extracts of R. sphenocleoides in Table 1. Generally, both ethanolic and aqueous extracts contain several types of active compounds such as flavonoids, glycosides, phenols, resins, saponins, tannins, furanocoumarin, triterpenoids, amino acids and carbohydrates. This is due to the use of ethanol which provides a polar medium. Consequently, polar compounds will be easily extracted. The aqueous extract did not contain alkaloids while the ethanolic extract contains alkaloids. Because of the use of ethanol as a high selectivity solvent of alkaloids compounds. ${ }^{15}$

\section{Effect of $\boldsymbol{R}$. sphenocleoides leaves extracts on haematological parameters}

This present study revealed the decrease in $\mathrm{RBC}, \mathrm{Hb}$, HCT, MCV, RDW, MPV, MCH and LY in all rats infected with E. histolytica parasite. This can be due to the destruction of red blood cells by E. histolytica. Also, it may be due to high E. histolytica numbers in the intestines of the rats which caused the digestive disturbance. This leads to a difficulty or inability in the absorption of iron by the body. ${ }^{16}$

In addition, the parasite consumes and degrades the red blood cell proteins which are mainly hemoglobin. ${ }^{17} \mathrm{On}$ another hand, the results showed an increase in $\mathrm{MCHC}$, PLT, PCT, WBC, MO and GR in E. bistolytica-infected rats. The increase in PLT might be due to haemolytic anaemia. In addition, the increase in $\mathrm{WBC}, \mathrm{MO}$ and GR suggests a boost in the immune system to resist the infection. ${ }^{18}$ Moreover, the increase in MCHC may be due to that the $\mathrm{RBC}$ is fragile or destroyed, or because of the present of some immature RBC into blood circulation which may cause an increase in MCHC values. This agrees with Kotepui et al. ${ }^{19}$ and Mehdi et al. ${ }^{6}$ they found that E. histolytica-infection rats it has an effect on $\mathrm{Hb}$, $\mathrm{MCV}$ and MCH values.

The present study showed that extracts of R. sphenocleoides demonstrated changes in erythrocytic parameter profiles in E. histolytica- infected rats at the dose of $500 \mathrm{mg} / \mathrm{kg}$. The significant increase in $\mathrm{RBC}, \mathrm{Hb}, \mathrm{HCT}, \mathrm{MCH}$ and $\mathrm{MCV}$ after oral administration of extracts of $\mathrm{R}$. sphenocleoides state that the extracts may consist of phytochemicals and compounds which stimulate the secretion or 
formation of erythropoietin which leads to enhance the production of red blood cells (erythropoiesis). Presence of antioxidant phytochemicals such as tannins and terpenoids in the extracts of $\mathrm{R}$ sphenocleoides perhaps responsible for the haemopoietic stimulating influences. This result agrees with Wambi et al. who stated that antioxidant phytochemicals in the extracts of the plant increased cells of haemopoietic origin in experimental animals significantly. ${ }^{20}$ Also, study Grassmann who stated that tannins, flavonoids and terpenes work to protect erythrocytes from the oxidative damage. ${ }^{21}$ This might have contributed to the increase in $\mathrm{Hb}$ and HCT observed in extracts treated groups. This result agrees to what was found by Enechi et al. who stated that crude extracts of Pleiocarpa mutica leaves increased in $\mathrm{Hb}$ and HCT in Plasmodium-berghei-infected mice. ${ }^{22}$

In the present study, the effects of extracts of R. sphenocleoides on platelets and their connected parameter profiles in E. histolytica-infected rats showed a significant decrease in PLT, MPV and PDW. The extracts may contain phytochemicals and compounds that are capable of maintaining the normal platelets in the blood and thus replenishment of lost blood and curbing anaemia that may be caused by the E. histolytica. This is a result consistent with earlier studies. ${ }^{23,24}$

In the present study, the effects of extracts of $R$. sphenocleoides on total WBC and differential WBC counts in E. histolyticainfected rats showed a significant decrease in WBC, $\mathrm{MO}$ and GR compared with the metronidazole group and the pre-treatment stage. The decrease in WBC may be a result of the reduction of the infection. This agrees with Bassey and Edoamodu who stated that some herbals extracts lead to a decrease in WBC in Plasmodium berghei infected mice. ${ }^{25}$

On the other hand, in the same stage, a significant increase was observed in LY. The increase in LY may be due to that the extracts contain bioactive ingredients that help dividing lymphocytes. Therefore, LY is involved in immune functions like the production of immunoglobulin and modulation of immune defense. This result agrees with Buncharoen et al. ${ }^{26}$ who stated that Temona aphylla extract leads to an increase of lymphocytes in the treated rats.

\section{CONCLUSION}

The findings of this study, that the efficiency of $R$. sphenocleoides extracts in improving blood standards through variations occurring in blood proportion and not adversely affect the haematological parameters better than Metronidazole drug.

\section{Ethics approval}

Institutional guidelines for the care and use of animals were followed. All procedures performed in the study involving animals were by the ethical standards of the institution or practice at which the study was conducted date 16/08/2018.

\section{ACKNOWLEDGEMENT}

The authors would like to acknowledge Dr. Rafiq Zakaria College for Women at Dr. Babasaheb Ambedkar Marathwada University for facilitating the accomplishment of the current study, also, thank Dr. Omar Bin ShuaibYemen for his make statistical analysis for this paper.

\section{CONFLICT OF INTEREST}

The authors declare no conflicts of interest.

\section{ABBREVIATIONS}

LSD: Least significant differences; RBC: Red blood cell; Hb: Hemoglobin; HCT: Haematocrit; MCV: Mean cell volume; MCH: Mean corpuscular hemoglobin; MCHC: Mean corpuscular hemoglobin concentration; RDW: Red cell distribution width; PLT: Platelet; PCT: Procalcitonin Test; MPV: Mean platelet volume, PDW: Platelet distribution width; WBC: Total white blood cell; LY: Lymphocyte MO: Monocyte; GR: Granulocytes.

\section{REFERENCES}

1. Kantor M, Abrantes A, Estevez A, Schiller A, Torrent J, et al. Entamoeba histolytica: Updates in clinical manifestation, pathogenesis and vaccine development. Can J Gastroenterol Hepatol. 2018;1-6.

2. Chachain NF, Jamil HA. Therapeutic effect of earthworm powder on the pathogenesis of Entamoeba histolytica in vivo. Pak J Biotechnol. 2017;14(4):643-51.

3. Verma AK, Verma R, Ahuja V, Paul J. Real-time analysis of gut flora in Entamoeba histolytica infected patients of Northern India. BMC Microbiol. 2012;12(1):1-11.

4. Inabo HG, Galadima M, Ogbodu LJ, Okuofu CA. Prevalence of E. histolytica and G. lamblia on primary school pupil in five rural villages around Kaduna and Zaria. Nig J Parasitol. 2014;21:61-8.

5. Mondal D, Petri WA, Sack RB, Kirkpatrick BD, Haque R. Entamoeba histolytica-associated diarrheal illness is negatively associated with the growth of preschool children: Evidence from a prospective study. Trans R Soc Trop Med Hyg. 2006;100(11):1032-8.

6. Mehdi MAH, Alarabi FY, Farooqui M, Pradhan V. Phytochemical screening and antiamebic studies of Tamaridus indica of leaves extract. Asian J Pharm Clin Res.2019;12(2):507-12.

7. Nowak P, Mastalska K, Loster J. Entamoeba histolytica - pathogenic protozoan of the large intestine in humans. J Clin Microbiol Biochem Technol. 2015;1(1):010-17.

8. Shirley DAT, Farr L, Watanabe K, Moonah S. A review of the global burden, new diagnostics and current therapeutics for amebiasis. Open forum Infect Dis. 2018;5(7):1-9.

9. Mehdi MAH, Alarabi FY, Omar GMN, Pradhan V. Effect of extracts on haematological parameters in albino rats Tamarindus indica infected with parasite Entamoeba histolytica. Asian J Pharm Pharmacol. 2019;5(5):889-94. 
10. Bansal D, Malla N, Mahajan RC. Drug resistance in amoebiasis. Indian J Med Res. 2006;123(2):115-8.

11. Wood Jl. A handbook of the Yemen flora. Royal Botanic Gardens, Kew, UK. 1997.

12. Abdo AA. Ethnobotany of ashemaitens region, Taiz government -Yemen (Master). Faculty of Education Aden-Aden University, Yemen. 2014.

13. Abdallah MS, DeWit HD. The Resedaceae: A taxonomical revision of the family (final instalment). Unknown Publisher. 1978;78-14.

14. Abdullah BM, Mehdi MAH, Fatema I, Pathan JM. GC-MS determination of bioactive compounds of Catha edulis Forsk, growing in Yemen. Our Heritage. 2020;68(38):375-85.

15. Escalona-Arranz JC, Pérez-Rosés R, Jiménez IL, Rodríguez-Amado J, Argota-Coello H, Cañizares-Lay J, et al. Chemical constituents of Tamarindus indica L. leaves. Revista Cubana de Química. 2010;22(3):65-71.

16. Obaid HM. The effect of Entamoeba histolytica and Giardia lamblia infection on some human hematological parameters. J Nat Sci Res. 2014;4(12):44-8.

17. Gavigan CS, Dalton JP, Bell A. The role of aminopeptidases in haemoglobin degradation in Plasmodium falciparum infected erythrocytes. Mol Biochem Parasitol. 2001;117(1):37-48.

18. Balogun EA, Adebayo JO, Zailani AH, Kolawole OM, Ademowo OG. Activity of ethanolic extract of Clerodendrum violaceum leaves against Plasmodium berghei. Agr Biol J North Am. 2009;1(3):307-12.
19. Kotepui M, Piwkham D, PhunPhuech B, Phiwklam N, Chupeerach C, Duangmano S. Effects of malaria parasite density on blood cell parameters. PLoS One. 2015;10(3):1-11.

20. Wambi C, Sanzari J, Wan XS, Nuth M, Davis J, Ko YH, et al. Dietary antioxidants protect hematopoietic cells and improve animal survival after total-body irradiation. Rad Res. 2008;169(4):384-96.

21. Grassmann J. Terpenoids as plant antioxidants. Vitamins and Hormones. 2005;72:505-35.

22. Enechi OC, Okenu BC, Ikechukwu UR. Antimalarial Activity and Effect of ethanol extract of Pleiocarpa mutica leaves on some haematological indices of Plasmodium berghei-Infected Mice. American-Eurasian J Agr Env Sci. 2016;16(5):860-7.

23. Kaur GJ, Arora DS. Bioactive potential of Anethum graveolens, Foeniculum vulgare and Trachyspermum ammi belonging to the family UmbelliferaeCurrent status. J Med Plants Res. 2010;4(2):087-94.

24. Oyedeji KO, Bolarinwa AF. Effect of metronidazole on haematological parameters in male albino rats. J Dental Med Sci. 2013;3(5):61-3.

25. Bassey $\mathrm{U}$, Edoamodu O. In vivo investigation of haematological and histological effects of leaves extracted from some herbals on Plasmodium berghei. Medbiotech J. 2018;2(1):147-52.

26. Buncharoen W, Saenphet S, Chomdej S, Saenphet K. Evaluation of biochemical, hematological and histopathological parameters of albino rats treated with Stemona aphylla Craib. extract. J Med Plants Res. 2012;6(27):4429-35.

\section{PICTORIAL ABSTRACT}
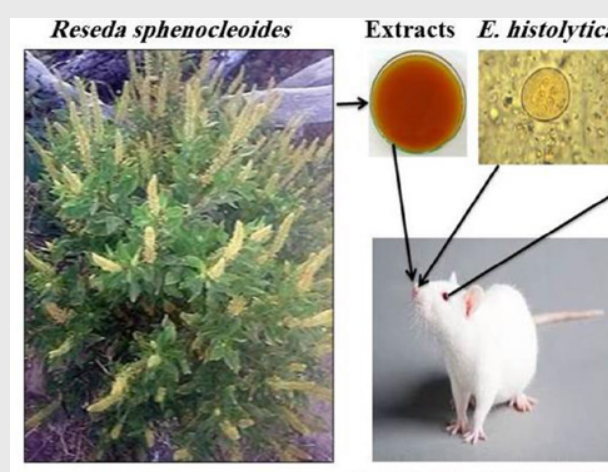

Rats infected with $E$. histolytic

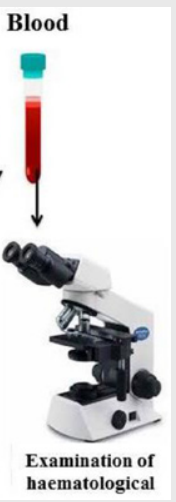

\section{SUMMARY}

The present study was designed to evaluate the changes in some heamatological parameters of E. histolyticainfected rats treated with extracts of $R$. sphenocleoides leaves.

The rats were infected by oral administration $\left(17 \times 10^{3}\right.$ cell $/ \mathrm{ml}$ ) of $E$. histolytica obtained from the stool. The crude extracts $R$. sphenocleoides were extracted with ethanol and distilled water. Additionally, chemical detection of alkaloids, flavonoids, glycosides, phenols, resins saponins, terpenes, sterols, tannins, furanocoumarin, triterpenoids, amino acids carbohydrates were carried out. The infected rats were treated by extracts $R$. sphenocleoides compared with metronidazole drug. This study that the $R$. sphenocleoides extracts showed improvement in haematological parameters in $E$. histolytica-infected rats better than Metronidazole drug.

\section{About Authors}

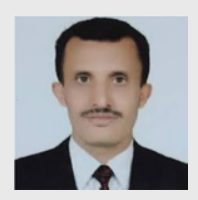

Mansour Abdulnabi Hadi Mehdi, Ph.D. scholar at Department of Zoology, Dr. Rafiq Zakaria College for Women, Dr. Babasaheb Ambedkar Marathwada University, Aurangabad, India. He has published 22 research papers in national and international journals.

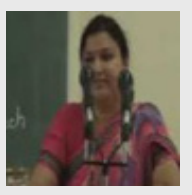

Prof. Dr. Vidya Pradhan, Vice-principal and Head Department of Zoology, Dr. Rafiq Zakaria College for Women, Aurangabad, Aurangabad (M.S.) India. Working Experience 27 years teaching zoology to UG and PG students. Research Guide 02 student awarded Ph.D., Published 130 Research papers in national and international journals. Research papers presented in National and International. At Mauirisus Malaysia, Srilanka, Thailand. Completed 2 major research project UGC. 


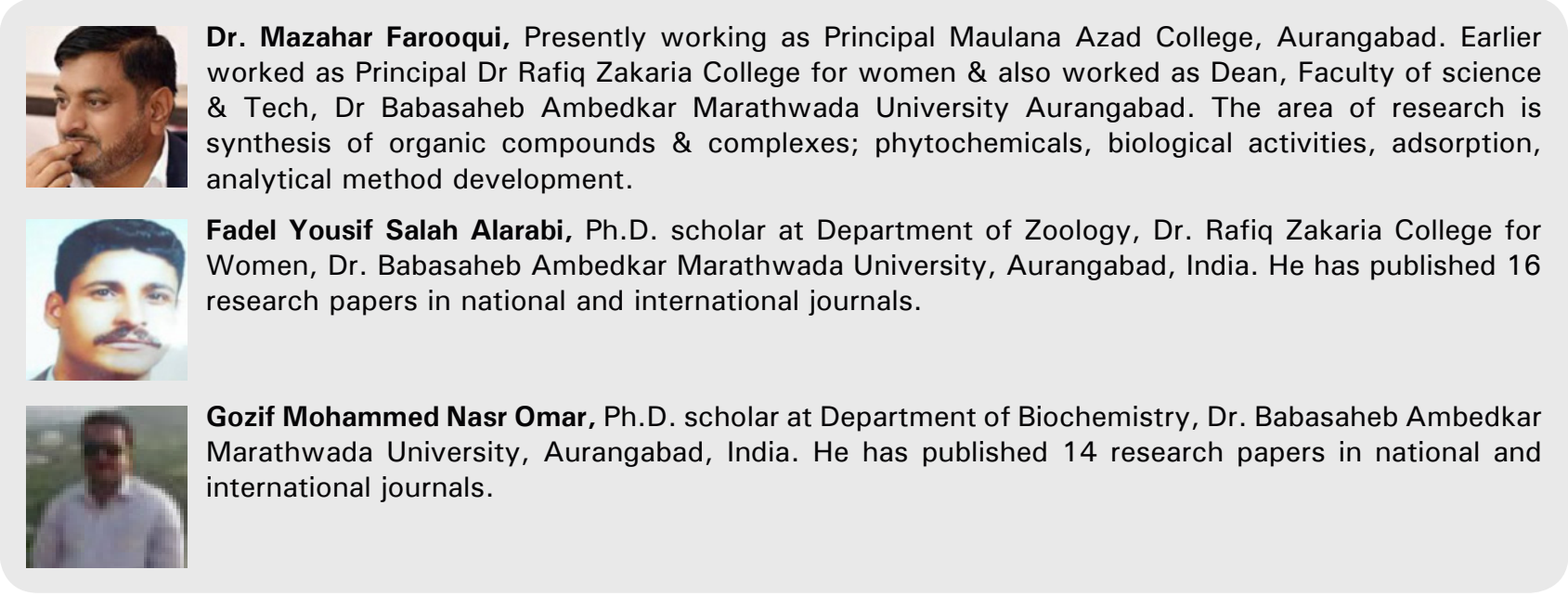

Cite this article: Mehdi MAH, Pradhan V, Farooqui M, Alarabi FYS, Omar GMN. Determination of Haematological Effects of Extracts of Reseda sphenocleoides Leaves in Albino Rats Infected with Entamoeba histolytica. Indian J of Pharmaceutical Education and Research. 2021;55(2):436-44. 